DOI https://doi.org/10.30525/978-9934-26-183-1-2

\title{
РОСЛИННІСТЬ БОТАНІЧНОГО ЗАКАЗНИКА МІСЦЕВОГО ЗНАЧЕННЯ «ВОРОНІЗЬКИЙ» (СУМСЬКА ОБЛАСТЬ)
}

\author{
Вакал А. П. \\ кандидат біологічних наук, \\ дочент кафедри біологї та методики навчання біології \\ Сумський державний педагогічний університет імені А. С. Макаренка
}

Литвиненко Ю. І.

кандидат біологічних наук,

дочент кафедри біологї та методики навчання біологї

Сумський державний педагогічний університет імені А. С. Макаренка

Москаленко М. П.

кандидат біологічних наук,

дочент кафедри біології та методики навчання біології

Сумський державний педагогічний університет імені А. С. Макаренка

м. Суми, Украӥна

Ботанічний заказник місцевого значення «Воронізький» розташований на південний захід від смт. Воронеж Шосткинського району Сумської області, на терасі р. Осота у іїі середній течії. Лісові масиви ботанічного заказника належать Воронізькому лісництву Державного підприємства «Шосткинське лісове господарство» і займають територію урочища «Дубина» (квартали 5-12). Ботанічний заказник «Воронізький» було створено 3 грудня 1980 року, і його площа складає 340 га $[2$, c. $87 ; 4)]$.

Згідно геоботанічного районування України територія досліджень знаходиться в межах Східноєвропейської провінції, Поліської підпровінції, Чернігівсько-Новгородсіверського округу, Шосткинського геоботанічного району [1, с. 116].

На території даного заказника найбільші площі (до $80 \%$ площі заповідного урочища) зайняті сосновими лісами. Значна частина їх $\epsilon$ похідними, що утворилися на місці зведених суборів. Перший ярус деревостану цих лісів формує сосна звичайна (Pinus sylvestris L.). Другий ярус утворюють клен гостролистий (Acer platanoides L.), місця липа серцелиста (Tilia cordata L.), дуб звичайний (Quercus robur L.), береза бородавчаста (Betula pendula Ronh.). У підліску можна зустріти ліщину звичайну (Corylus avellana L.), бруслину бородавчасту (Evonimus 
verrucosa Scop.), бузину червону (Sambucus racemosa L.). Характерною рисою заказника $\epsilon$ поширення папоротей. У деяких місцях їх проективне покриття може досягати 70-80 \%. Переважає за кількістю екземплярів щитник чоловічий (Dryopteris filix-mas (L.) Schott), значну домішку утворює щитник шартський (Dryopteris carhusiana (Vill) H.P.Fuchs.) і голокучник дубовий (Gymnocarpium dryopteris (L.) Newm.). Також трапляються ділянки, де в трав'яному покриві переважає барвінок малий (Vinca minor L.).

Нерідко трапляються свіжі та вологі субори 3 добре розвиненим чагарничковим ярусом із чорниці (Vaccinium myrtillus L.).

На підвищеннях рельєфу можна зустріти невеликі за площею ділянки дубових лісів. Це світлі, майже без підліску, ліси, в яких збереглися старі дуби висотою 26-28 м. У ярусі трав'янистих рослин домінують пирій повзучий (Elytrigia repens (L.) Nevski) і мітлиця тонка (Agrostis tenuis Sibth). Також досить часто зустрічаються буквиця лікарська (Betonica officinalis L.s.I.), первоцвіт весняний (Primula veris L.), серпій фарбувальний (Serratula tinctoria L.).

Серед березових лісів (кв. 8), які займають не значні площі, переважають похідні угруповання, що виникли на місці зведених дубово-соснових і соснових лісів. Здебільшого це березняки різнотравні та зеленомохові.

Також на території заказника $\epsilon$ болота, які розміщуються в притерасній частині р. Осоти. Тут є смуги вільшняків очеретяних i осокових, а також зарості верби попелястої (Salix cinerea L.) 3 переважанням у трав'яному покриві осок омської (Carex elata subsp. omskiana (Meinsh.) Jalas ) i гострої (Carex acuta L.).

Деревостан вільшняків монодомінантний, одноярусний, представлений вільхою клейкою (Alnus glutinosa (L.) Gaertn.). Ярус кущів слабко розвинений і в ньому переважає крушина ламка (Frangula alnus Mill). Домінантами ярусу трав'янистих рослин у різних групах асоціацій є такі види, як очерет звичайний (Phragmites australis (Cav.) Trin. ex Steud.), осоки гостра та побережна (Carex riparia Curt.), тощо. Серед різнотрав'я доволі часто зустрічаються вербозілля звичайне (Lysimachia vulgaris L.), вовче тіло болотне (Comamum palustre L.), півники болотні (Iris pseudacorus L.), частуха подорожникова (Alisma plantago-aquatica L.).

На території ботанічного заказника «Воронізький» виявлено місцезростання 3 видів рослин, які включені до офіційного переліку видів рослин, які не занесені до Червоної книги України, але $\epsilon$ рідкісними або такими, що перебувають під загрозою зникнення на території Сумської області, а саме - плаун булавовидний (Lycopodium clavatum L.), голокучник дубовий і наперстянка великоцвіта [3, c. 106-107]. 


\title{
Література:
}

1. Геоботанічне районування Української РСР. Київ : Наук. думка, 1977. $303 \mathrm{c}$.

2. Природно-заповідний фонд Сумської області: Атлас-довідник. Київ : ТОВ «Українська Картографічна Група», 2019.96 с.

3. Офіційні переліки регіонально рідкісних рослин адміністративних територій України (довідкове видання). Київ: Альтерпрес, 2012. 148 с.

4. Ботанічні заказники Сумської області. : веб-сайт. URL: https://uk.погода-синоптик.pp.ua > .. (дата звернення 20.12.2021).

DOI https://doi.org/10.30525/978-9934-26-183-1-3

\section{ECOLOGICAL AND HISTORICAL ANALYSIS OF THE FLORA OF THE KREMENETS MOUNTAINS NATIONAL NATURAL PARK}

\author{
Lisova N. 0. \\ Candidate of Biological Sciences, \\ Associate Professor at the Department of Geoecology and Methods \\ of Teaching Environmental Sciences \\ Ternopil Volodymyr Hnatiuk National Pedagogical University
}

Syvyj M. Ya.

Doctor of Geographic Sciences, Professor at the Department of Geography and its Teaching Methods

Ternopil Volodymyr Hnatiuk National Pedagogical University

Havryshok B. B.

Candidate of Geographic Sciences, Associate Professor at the Department of Geography and its Teaching Methods

Ternopil Volodymyr Hnatiuk National Pedagogical University

Ternopil, Ukraine

Nature reserve areas are of important phytocenotic, ecological, historical, landscape-aesthetic, educational and even economic importance. One of these are the Kremenets Mountains National Nature Park. 